\title{
Phytoplankton assemblages of two intermittently open and closed coastal lakes in SE Australia
}

\author{
Dongyan Liu ${ }^{\mathrm{a}, *}$, R. John Morrison ${ }^{\mathrm{a}}$, Ronald J. West ${ }^{\mathrm{b}}$

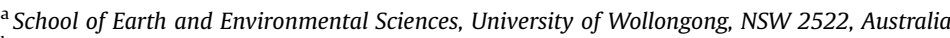 \\ ${ }^{\mathrm{b}}$ Australian National Centre for Ocean Resources and Security, University of Wollongong, NSW 2522, Australia
}

\section{A R T I C L E I N F O}

Article history:

Available online 27 May 2012

\section{Keywords:}

estuary

nutrient

phytoplankton

Lake Illawarra

Burrill Lake

\begin{abstract}
A B S T R A C T
Species composition and biomass of phytoplankton assemblages of a heavily impacted lake (Lake Illawarra) and a less impacted lake (Burrill Lake) in the South-Eastern region of Australia were compared based on bimonthly samples from three sites in each lake collected between April 2005 and April 2007. Lake Illawarra was generally characterized by higher nutrient concentrations and lower salinity than Burrill Lake. Phytoplankton assemblages displayed significant differences between the two lakes in terms of the dominant species composition and patterns of seasonal change rather than biomass. Diatoms were the dominant species in Lake Illawarra on most sampling occasions. In contrast, dinoflagellates (including toxic species) dominated in Burrill Lake during most seasons. Seasonal succession of phytoplankton in the two lakes did not follow the strict spring maximum that is generally observed in temperate waters. In Burrill Lake, maximum phytoplankton biomass often occurred in winter, while the maximum biomasses in Lake Illawarra occurred in autumn, winter and spring. The significant difference of nutrient structure between two lakes and warm temperate regime was regarded as important factors to affect these results. The results suggested care should be taken when relying on estuary health "indicators", such as chlorophyll a, rather than more detailed investigations of phytoplankton species compositions.
\end{abstract}

(ㄷ) 2012 Elsevier Ltd. All rights reserved.

\section{Introduction}

In many regions of the world, coastal lakes are a dominant landscape feature (Woodroffe, 2003), providing a diversity of shallow water and wetland habitats, and playing a crucial role in the life history of many aquatic species, particularly water birds and fishes (e.g., Chafer and Brandis, 2001; Jones and West, 2005). They also represent desirable areas for development, particularly residential development, and many coastal lakes and associated waterways have become major tourist centres around the world. In the South-Eastern region of Australia, between Sydney and Eden (New South Wales, NSW), there are over sixty major coastal lakes ranging in size and geomorphology, as well in the degree to which their catchments have been developed (Roy et al., 2001). A few of these coastal lakes remain in a relatively pristine state, while others are surrounded by various proportions of agricultural, residential and, more rarely, industrial development. For the most part, these

\footnotetext{
* Corresponding author. Present address: Yantai Institute of Coastal Zone Research, Chinese Academy of Sciences, 17th Chunhui Road, Laishan district, Yantai, Shandong 264003, PR China.

E-mail address: dyliu@yic.ac.cn (D. Liu).
}

coastal lakes are in relatively good condition, but there is an increasing demand for further catchment development as coastal towns and villages grow.

The general structure of coastal lakes in this region is a series of small rivers or creeks flowing into a mud basin, which is open to the sea through a narrow channel (Roy et al., 2001). However, the overall size, shape, dimensions, freshwater flows and tidal exchange vary considerably between individual situations. Importantly, as a result of relatively low and seasonally inconsistent rainfall ( $\sim 1000 \mathrm{~mm}$ per annum) and high wave energies along the SE Australian coastline, many of these lakes are only intermittently open to the sea (Roy et al., 2001). The term "Intermittently Closed and Open Lakes and Lagoons" (ICOLLs) has been coined to describe these water bodies. The degree to which the entrances of individual lakes open and close to the ocean is dependent on many localized climatic and geomorphic factors, and this results in a range of situations, including coastal lakes that rarely open to those that rarely close. The corresponding water quality conditions, sediment characteristics and flora and fauna likewise vary considerably between individual situations (Roy et al., 2001).

Detailed information useful for the management of the coastal lakes in SE Australia is generally unavailable except for the more populated areas and is usually limited in nature. Local governments 
in the region generally monitor water quality, but the data are often inconsistent and in response to local health or related issues. Mapping of major estuarine habitats has been carried out several times for most coastal lakes and there have been limited investigations of seagrass, fish and fisheries at some locations (e.g., West, 2004). Phytoplankton as the most important primary producer have been the subject of very few studies in these lakes, although the increased incidence of harmful algal blooms (NSW Department of Water, 2009), particularly those involving toxic species, is of great concern for oyster farming, fishing and tourism.

In this study, the phytoplankton species composition and abundance in Lake Illawarra and Burrill Lake, two large coastal lakes in SE Australia with different catchment development and eutrophication status, were studied. A detailed comparison of the phytoplankton assemblages combined with related environmental factors was made to determine whether any of the observed differences in community structure could reflect the specific characteristics of the water bodies. The primary objective of this study was to increase our understanding for the indicative role of phytoplankton assemblage in catchment development and water quality.

\section{Materials and methods}

\subsection{Study sites}

This study was carried out in two relatively large coastal lakes in South-Eastern (SE) Australia - Lake Illawarra and Burrill Lake. Lake Illawarra is a large shallow coastal lake with extensive inter-tidal foreshore located $80 \mathrm{~km}$ south of Sydney (Fig. 1). The surface area of the lake is $36.3 \mathrm{~km}^{2}$, the maximum depth about $3 \mathrm{~m}$ and it has three main sources of freshwater runoff, namely: Mullet Creek, Duck Creek and Macquarie Rivulet. Lake Illawarra is considered a regional icon, playing an important role in the life of the people living in the Wollongong-Shellharbour region (Morrison and West, 2004). There are about 90,000 residents living around the $270 \mathrm{~km}^{2}$ catchment (ABS, 2003) and the lake has been impacted significantly by human activities, particularly since the arrival of Europeans some 200 years ago (Morrison and West, 2004). Residential and industrial developments cover approximately $23 \%$ of the catchment, rural areas make up about $40 \%$ and the remainder of the catchment is forested. Large quantities of domestic and industrial waste-waters, urban drainage and agricultural effluents are considered the main contributors to the high nutrient concentrations (WBM, 2003; Morrison and West, 2004). Increased eutrophication and the decline of water quality have caused a series of environmental problems over the past 50 years, including harmful algal blooms (HABs), seagrass loss and macroalgal blooms (Ajani et al., 2001; Rutten et al., 2004; West, 2004).

Burrill Lake is located about $200 \mathrm{~km}$ south of Sydney (Fig. 1). This coastal lake has a water surface area of about $4.1 \mathrm{~km}^{2}$ and a maximum depth of about $9 \mathrm{~m}$ (SCC, 2002). The freshwater discharge is primarily from Stony Creek, which enters from the north. In comparison to Lake Illawarra, there are about 1410 residents living around the $78 \mathrm{~km}^{2}$ catchment of Burrill Lake (ABS, 2003 ) occupying about 3\% of the catchment. A large proportion of the remaining catchment is covered with dry sclerophyll forests, although $37 \%$ of the area is subject to some non-intensive agriculture (e.g., cattle grazing). There is virtually no industrial development within the catchment and water quality in the lake has generally been regarded as good by the local government authorities (SCC, 2002).

\subsection{Sampling methods}

Three sampling sites were chosen to represent the different lake environments (lake entrance, lake basin and freshwater source) and located using GPS (Table 1 and Fig. 1). Each site was investigated bimonthly from April 2005 to April 2007 and physical parameters, including water temperature, salinity, turbidity, DO and $\mathrm{pH}$ measured in surface waters using an YSI (6820, USA) multiprobe water quality meter, calibrated before each sampling event.

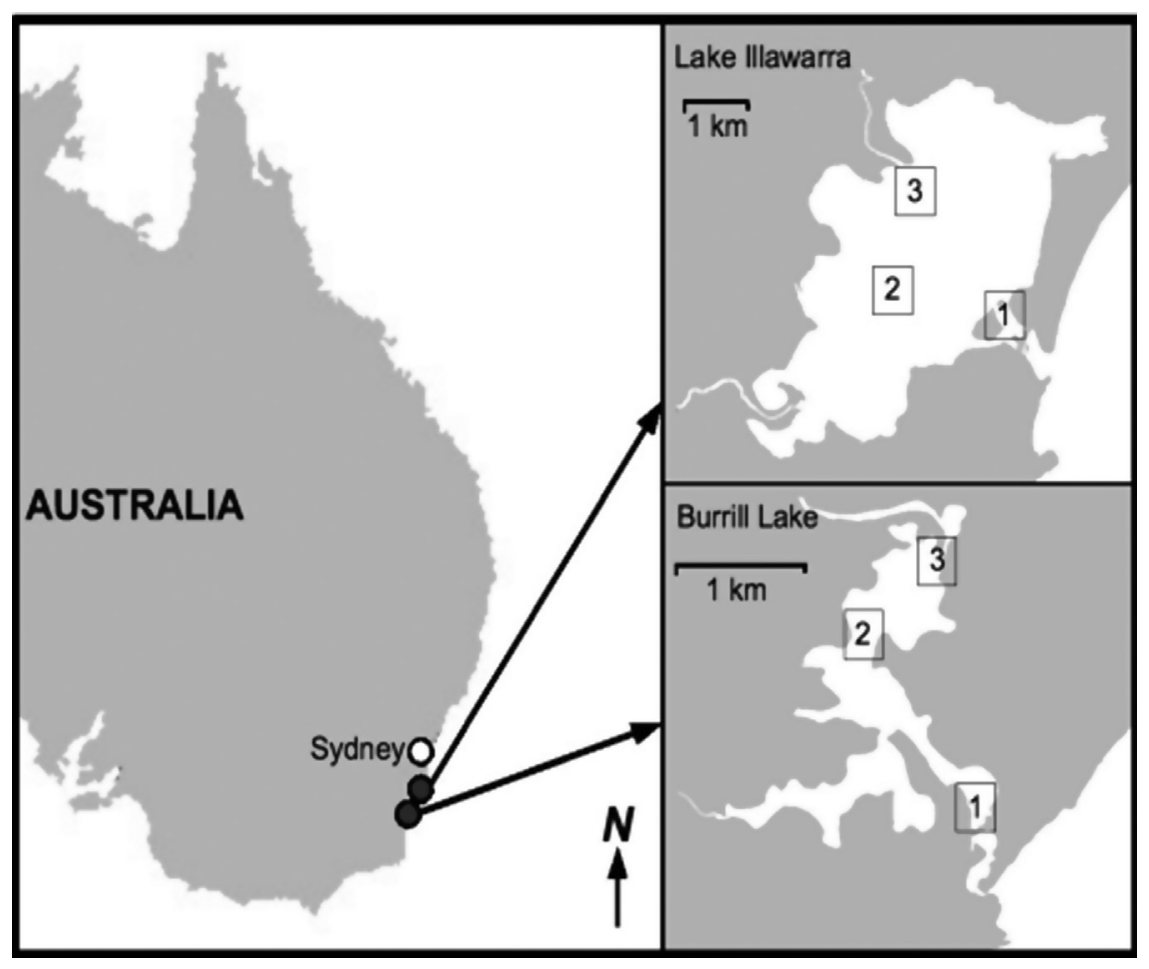

Fig. 1. Study sites (labeled 1-3) in Lake Illawarra and Burrill Lake, located in SE Australia. 
Table 1

Location of the sampling sites in Lake Illawarra and Burrill Lake (NSW, Australia).

\begin{tabular}{lllll}
\hline Estuary & Site & Latitude & Longitude & Location \\
\hline Lake Illawarra & Site 1 & $34.528339^{\circ} \mathrm{S}$ & $150.858765^{\circ} \mathrm{E}$ & Entrance channel \\
& Site 2 & $34.523389^{\circ} \mathrm{S}$ & $150.835075^{\circ} \mathrm{E}$ & Central lake \\
& Site 3 & $34.502313^{\circ} \mathrm{S}$ & $150.840225^{\circ} \mathrm{E}$ & Near freshwater source \\
Burrill Lake & Site 1 & $35.384921^{\circ} \mathrm{S}$ & $150.447936^{\circ} \mathrm{E}$ & Entrance channel \\
& Site 2 & $35.367286^{\circ} \mathrm{S}$ & $150.431457^{\circ} \mathrm{E}$ & Central lake \\
& Site 3 & $35.359306^{\circ} \mathrm{S}$ & $150.441155^{\circ} \mathrm{E}$ & Near freshwater source \\
\hline
\end{tabular}

Rainfall data were provided for weather stations located in each catchment by the New South Wales Climate Service Centre (Australia Bureau of Meteorology). At each site and on each sampling occasion, approximately $50 \mathrm{~mL}$ of surface lake water was collected for nutrient analyses and $3 \mathrm{~L}$ for determining Chlorophyll a (Chl a) and phytoplankton species composition and cell abundance.

Water samples for nutrient analyses were filtered in the field, frozen and stored before measurement. Chemical parameters, including dissolved inorganic nitrogen ( $\mathrm{DIN}=\mathrm{NO}_{3}^{-}+\mathrm{NO}_{2}^{-}+\mathrm{NH}_{4}^{+}$), dissolved inorganic phosphorus (DIP) and dissolved inorganic silicate (DISi) were determined with an LACHAT Quik-chem 8000 Nutrient Auto-analyzer using standard protocols (APHA et al., 1998). The limits of detection were $0.14 \mu \mathrm{M}$ for $\mathrm{NO}_{3}^{-}, \mathrm{NO}_{2}^{-}$and $\mathrm{NH}_{4}^{+}, 0.01 \mu \mathrm{M}$ for $\mathrm{PO}_{4}^{3-}$ and $1.24 \mu \mathrm{M}$ for DSi, respectively. Appropriate quality control procedures were adopted involving the use of standard samples, blanks and replicates.

The $3 \mathrm{~L}$ water sample was stored on ice until returned to the laboratory, where a known volume (in triplicate) was filtered through $0.76 \mu \mathrm{m}$ Whatman GF/F glass filters, usually on the day of collection. The glass filters, containing $\mathrm{Chl} \mathrm{a}$, were stored in a dark and frozen condition. Chl a concentration was measured using the non-acidification spectrophotometric method (Jeffrey and Humphrey, 1975). Chl a was extracted from the filters using $90 \%$ acetone in the dark for $24 \mathrm{~h}$ at $4{ }^{\circ} \mathrm{C}$; the absorptions of the resultant solutions were measured using a spectrometer (Shimadzu UV-1700), after centrifugation. Absorptions at 630, 647, 664 and $750 \mathrm{~nm}$ were measured and $\mathrm{Chl}$ a concentration calculated.

The remaining water was decanted into a plastic bottle and preserved using formaldehyde ( $5 \%$ final concentration) for determining of phytoplankton species composition and cell abundance. Phytoplankton samples were analyzed using Utermöhl (1958) method in laboratory. Preserved samples $(20 \mathrm{~mL})$ were left for $24 \mathrm{~h}$ to allow for sinking in counting chamber. Cell abundance was counted and species identified under an inverted microscope (Olympus CKX31) at $\times 100$ and $\times 400$ magnifications. Taxonomy and nomenclature were assessed by reference to Fenner et al. (1976), Hasle (1976), Hasle and Syvertsen (1997) and Guo and Qian (2003).

\subsection{Data analysis}

Multi-linear regression analyses between the phytoplankton biomass and environmental factors were conducted using the SPSS 13.0 statistical software. Non-parametric multidimensional scaling was used to explore relationships between the phytoplankton species composition for specific site and season combinations.

\section{Results}

\subsection{Physical parameters of two lakes}

Water temperatures showed little difference among sites or between lakes during the sampling period (Fig. 2A and D). They were characterized by expected seasonal changes with higher temperature in summer (December) and lower in winter (July). The ranges of annual water temperature were $13.2-25.8{ }^{\circ} \mathrm{C}$ in Lake Illawarra and $13.7-25.5{ }^{\circ} \mathrm{C}$ in Burrill Lake, reflecting the warm temperate climatic regime of the region. In addition, the annual data showed that water temperatures were above $20^{\circ} \mathrm{C}$ for about $50-60 \%$ of a year in this region (Fig. $2 A$ and D).

A higher salinity was observed in Burrill Lake during the sampling period compared to Lake Illawarra (Fig. 2B and E). Salinity in Lake Illawarra ranged from 22.7 to 28.4 with an overall mean of 26.4 (Fig. 2B), while salinity in Burrill Lake varied from 25.3 to 34.7 with a mean of 31.7 (Fig. 2E). The sites adjacent to the creek entrances (Site 3 in each lake) usually had lower salinity values, although differences were often relatively small. Moderate to large rainfall events in wet season (March-May and September-November) can significantly affect the salinity in these lakes, which have only intermittent connection to the sea.

Turbidity was generally higher in Lake Illawarra (Fig. 2C) compared to Burrill Lake (Fig. 2F). In Lake Illawarra, about $63.3 \%$ of data was below 5 NTU (0.7-5 NTU), while $36.6 \%$ of values were above 10 NTU (10.2-22 NTU) (Fig. 2C). By comparison, about $92.5 \%$ of data were below 5 NTU (0.2-4.9 NTU) in Burrill Lake and turbidity only exceeded 10 NTU in April 2006 and April 2007 due to heavy rain (Fig. 2F). In addition, green algal bloom (Coelastrum sp.) at Site 3 of Burrill Lake in April 2007 was also an important cause for high turbidity (20.3 NTU) (Fig. 2F).

\subsection{Dissolved nutrients - Lake Illawarra}

During the sampling period, dissolved inorganic nitrogen (DIN) concentrations, averaged across sites within Lake Illawarra (Table 2), were generally below $2.0 \mu \mathrm{M}$ and ranged from 0.33 to $3.38 \mu \mathrm{M}$ (mean $=1.60 \mu \mathrm{M}$ ). DIN values were mainly composed of ammonia, which accounted for $74 \%$ of total DIN. The monthly trend in DIN during 2005 and 2006 for each of the sites in Lake Illawarra (Fig. 2A) indicated that concentrations were generally higher in autumn (March and April) and winter (May-July) and lower in spring (September-November), probably reflecting a greater biological uptake in spring in this system. DIP concentrations, when averaged across sites within Lake Illawarra (Table 2), ranged from $0.42 \mu \mathrm{M}$ to $1.92 \mu \mathrm{M}$ (mean $=0.88 \mu \mathrm{M})$, while DSi concentrations (Table 2) varied from $6.26 \mu \mathrm{M}$ to $18.1 \mu \mathrm{M}$ (mean $=10.5 \mu \mathrm{M}$ ). The seasonal patterns of DIP and DISi displayed a similarity with DIN being characterized by an autumn-winter peak and a spring fall (Fig. 2B and C). The DIN:DIP ratio for Lake Illawarra had a mean value of 2.44 and a range of $0.07-19.0$ (Fig. 4). More than $95 \%$ of these DIN:DIP and DIN:DISi ratios were below 6 (i.e., DIN:DIP $<6: 1$ ) and 0.5 during the sampling period, respectively. These nutrient structures indicated that Lake Illawarra was nitrogen limited on most of the sampling occasions.

\subsection{Dissolved nutrients - Burrill Lake}

For Burrill Lake, DIN concentrations, averaged across all sites, varied from $0.26 \mu \mathrm{M}$ to $3.02 \mu \mathrm{M}$ with a mean of $1.22 \mu \mathrm{M}$ during the sampling period (Table 2). Ammonia contributed about $60 \%$ to the DIN pool in this lake. DIP concentrations were generally below $0.5 \mu \mathrm{M}$ with a mean of $0.28 \mu \mathrm{M}$ (Table 2). DISi concentrations ranged from $4.48 \mu \mathrm{M}$ to $51.2 \mu \mathrm{M}$ with a mean of $13.9 \mu \mathrm{M}$ (Table 2). DIN (Fig. 2D) and DISi (Fig. 2F) in Burrill Lake displayed a seasonal pattern with high values in winter (June) and low values in spring or summer in 2005 and 2006. In contrast, DIP concentrations did not show a regular seasonal pattern during the sampling period and higher DIP values were observed at Site 3 (overall mean $=0.57 \mu \mathrm{M})$ compared with Site $1($ overall mean $=0.13 \mu \mathrm{M})$ 
A

LAKE ILLAWARRA

Temperature

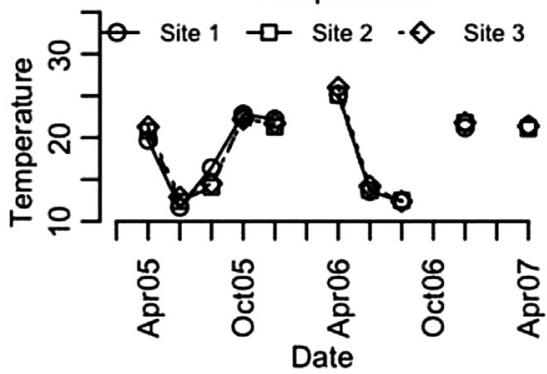

B
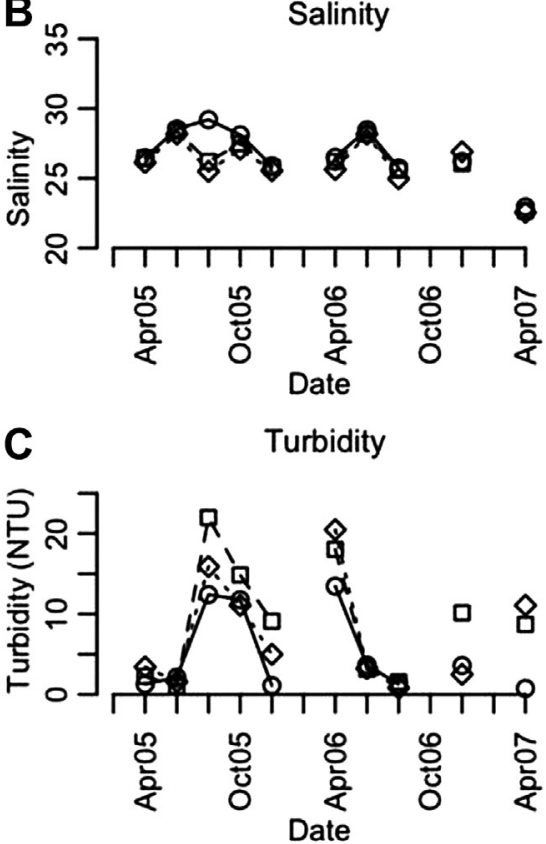

D BURRILL LAKE

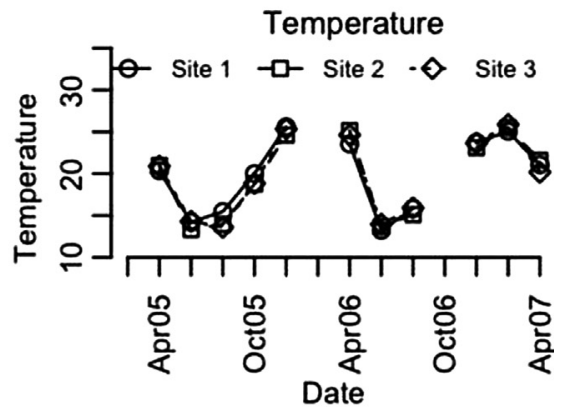

E

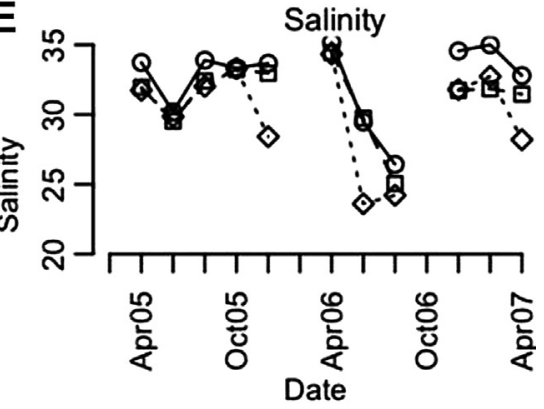

$\mathbf{F}$

Turbidity

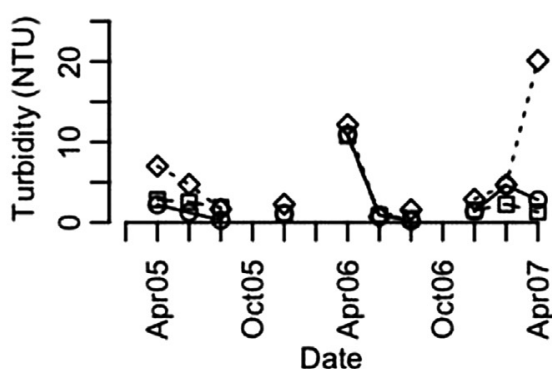

Fig. 2. Temperature, salinity and turbidity of surface waters at each of the three sites in Lake Illawarra (A, B, C) and Burrill Lake (D, E, F).

and Site 2 (overall mean $=0.16 \mu \mathrm{M}$ ). A very different pattern of DIN:DIP was found in Burrill Lake, compared to Lake Illawarra (Fig. 4). The DIN:DIP ranged from 0.10 to 75.3 with a mean of 14.5 during the sampling period (Fig. 3D). About 63\% of the values had DIN:DIP $<10: 1 ; 15 \%$ of data were in the range $10-20$ (i.e., close to the Redfield Ratio); and, $22 \%$ of the data were above 20. DIN:DISi ratio in Burrill Lake showed similar pattern with Lake Illawarra. This result showed that $\mathrm{N}$-limitation was common in Burrill Lake, but Plimitation could occur occasionally.

\subsection{Phytoplankton species composition}

In general, phytoplankton species composition did not show major difference between the two lakes, which were mainly composed of two groups, diatoms and dinoflagellates. One hundred and twenty species of phytoplankton were identified in Lake Illawarra, including 86 diatoms, 30 dinoflagellates and a small number of Chlorophyta, Cyanophyta and Coccolithophorids (Table 3). In Burrill Lake, 106 species were observed with 71 diatoms, 30 dinoflagellates and a few Chlorophyta, Cyanophyta and Coccolithophorids (Table 3). A majority of temperate water species, combined with a small number of warm water species (e.g., Hemidiscus haedmannianus; Prorocentrum micans), was identified in samples from the two lakes, reflecting the warm temperate climatic regime of SE Australia (Table 3). A combination of brackish and marine phytoplankton species was observed in two lakes, typical of estuaries with the variable salinity (Table 3). Moreover, brackish species in Lake Illawarra (38.3\%) made up a higher proportion of species than that in Burrill Lake (28.3\%), indicating the different salinity status between two lakes (higher in Burrill Lake; lower in Lake Illawarra). Species composition at the sites adjacent to the creek entrances (Site 3 in each lake) indicated the impact of freshwater discharge. For example, the diatoms, Cocconeis placentula and Rhabdonema adriaticum which are known to prefer freshwater to brackish waters rather than marine, were dominant. As well, a number of toxic species were widely observed during sampling (e.g., Prorocentrum minimum, Alexandrium tamarense, Akashiwo sanguinea, Dinophysis fortii) (Table 3).

\subsection{Annual pattern of phytoplankton assemblages in Lake Illawarra}

The annual pattern of phytoplankton assemblage displayed obvious spatial and temporal changes during the sampling period (April 2005-April 2007). The characteristics of phytoplankton assemblages indicated that biomass peaks could be expected from autumn to spring and then fell in summer. Diatoms dominated in most months in this lake, but dinoflagellates and green algae can be dominant in some seasons. 
LAKE ILLAWARRA

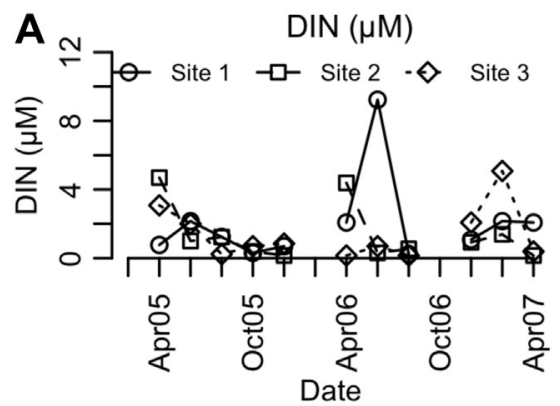

B
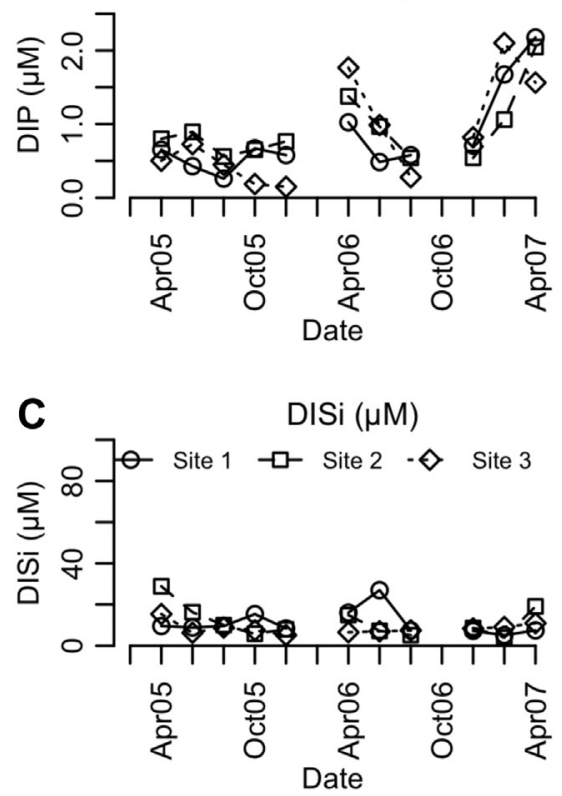

BURRILL LAKE

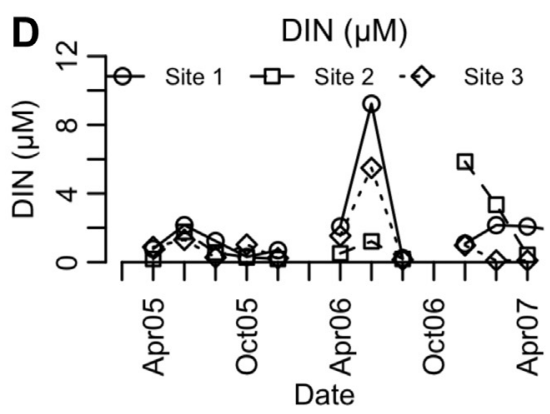

E $\quad \operatorname{DIP}(\mu \mathrm{M})$
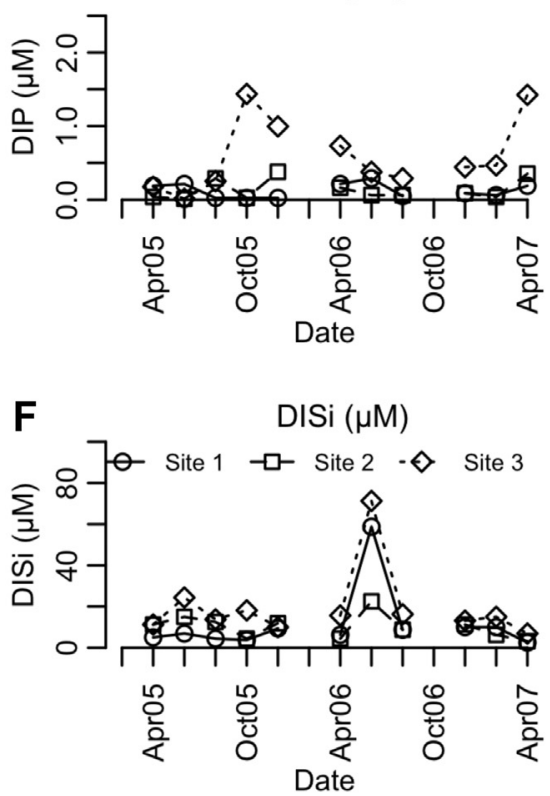

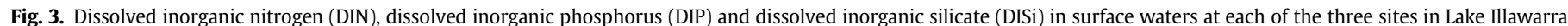
$(\mathrm{A}, \mathrm{B}, \mathrm{C})$ and Burrill Lake (D, E, F).

In 2005, Chl a and cell abundance (average values from the three sites) displayed an obvious spring maximum (October 2005, Table 2, Fig. 5A and B). The maximum biomass was mainly contributed by diatom species (e.g., Cylindrotheca closterium; Thalassiosira rotula) (Fig. 6). Dinoflagellates (Ceratium furca, Prorocetrum lima, and Akashiwo sanguine) were only dominant in some seasons, especially in autumn (e.g., April 2005) and winter (e.g.,
June 2005) (Fig. 6). Over the whole year, these data indicated that diatoms were dominant in Lake Illawarra in most months (Fig. 6).

In 2006, phytoplankton exhibited high abundance from April 2006 to June 2006 (Table 2, Fig. 5A and B). Diatom species (e.g., Cylindrotheca closterium, Chaetoceros curvisetus and Pesudo-nitzschia pungens) contributed the majority of the biomass over the whole year as 2005 (Fig. 6). Dinoflagellate dominance was not observed in

Table 2

Nutrient concentrations ( $\mu \mathrm{M})$ and phytoplankton biomass (the average values of three sites) in Lake Illawarra and Burrill Lake for the period April 2005-April 2007.

\begin{tabular}{|c|c|c|c|c|c|c|c|c|c|c|}
\hline \multirow[t]{2}{*}{ Items date } & \multicolumn{5}{|c|}{ Lake Illawarra } & \multicolumn{5}{|c|}{ Burrill Lake } \\
\hline & $\begin{array}{l}\text { DIN } \\
(\mu \mathrm{M})\end{array}$ & $\begin{array}{l}\text { DIP } \\
(\mu \mathrm{M})\end{array}$ & $\begin{array}{l}\text { DSi } \\
(\mu \mathrm{M})\end{array}$ & $\begin{array}{l}\text { Chl a } \\
(\mu \mathrm{g} / \mathrm{L})\end{array}$ & $\begin{array}{l}\text { Cells } \\
\left(\times 10^{4} \text { cells/L }\right)\end{array}$ & $\begin{array}{l}\text { DIN } \\
(\mu \mathrm{M})\end{array}$ & $\begin{array}{l}\text { DIP } \\
(\mu \mathrm{M})\end{array}$ & $\begin{array}{l}\text { DSi } \\
(\mu \mathrm{M})\end{array}$ & $\begin{array}{l}\text { Chl a } \\
(\mu \mathrm{g} / \mathrm{L})\end{array}$ & $\begin{array}{l}\text { Cells } \\
\left(\times 10^{4} \text { cells } / \mathrm{L}\right)\end{array}$ \\
\hline April 2005 & 2.88 & 0.66 & 18.1 & 3.47 & 3.51 & 0.98 & 0.14 & 9.00 & 4.57 & 9.50 \\
\hline June 2005 & 1.76 & 0.69 & 10.6 & 1.21 & 4.49 & 1.36 & 0.10 & 15.7 & 7.96 & 23.4 \\
\hline August 2005 & 0.88 & 0.42 & 9.60 & 2.06 & 2.32 & 0.69 & 0.19 & 10.2 & 3.68 & 18.9 \\
\hline October 2005 & 0.48 & 0.51 & 9.60 & 9.25 & 12.6 & 0.52 & 0.51 & 8.90 & 3.10 & 20.3 \\
\hline December 2005 & 0.57 & 0.51 & 7.40 & 2.94 & 8.84 & 0.26 & 0.47 & 10.5 & 3.65 & 3.10 \\
\hline March 2006 & 2.24 & 1.40 & 12.6 & 4.05 & 10.5 & 0.76 & 0.39 & 9.30 & 2.82 & 5.20 \\
\hline June 2006 & 3.38 & 0.82 & 13.9 & 4.00 & 10.8 & 3.02 & 0.25 & 51.2 & 4.08 & 21.9 \\
\hline August 2006 & 0.33 & 0.47 & 6.90 & 1.47 & 4.79 & 0.21 & 0.14 & 11.4 & 1.58 & 3.30 \\
\hline December 2006 & 1.37 & 0.70 & 8.30 & 3.83 & 2.11 & 2.76 & 0.22 & 11.9 & 3.45 & 4.10 \\
\hline February 2007 & 2.88 & 1.62 & 6.30 & 5.79 & - & 1.94 & 0.19 & 10.6 & 12.4 & - \\
\hline April 2007 & 0.88 & 1.92 & 12.6 & 8.53 & 4.18 & 0.57 & 0.66 & 4.50 & $22.77^{*}$ & $139.1^{*}$ \\
\hline
\end{tabular}

\footnotetext{
* Two high average values in Burrill Lake at site 3 in April 2007 were caused by a Coelastrum sp. bloom.
} 

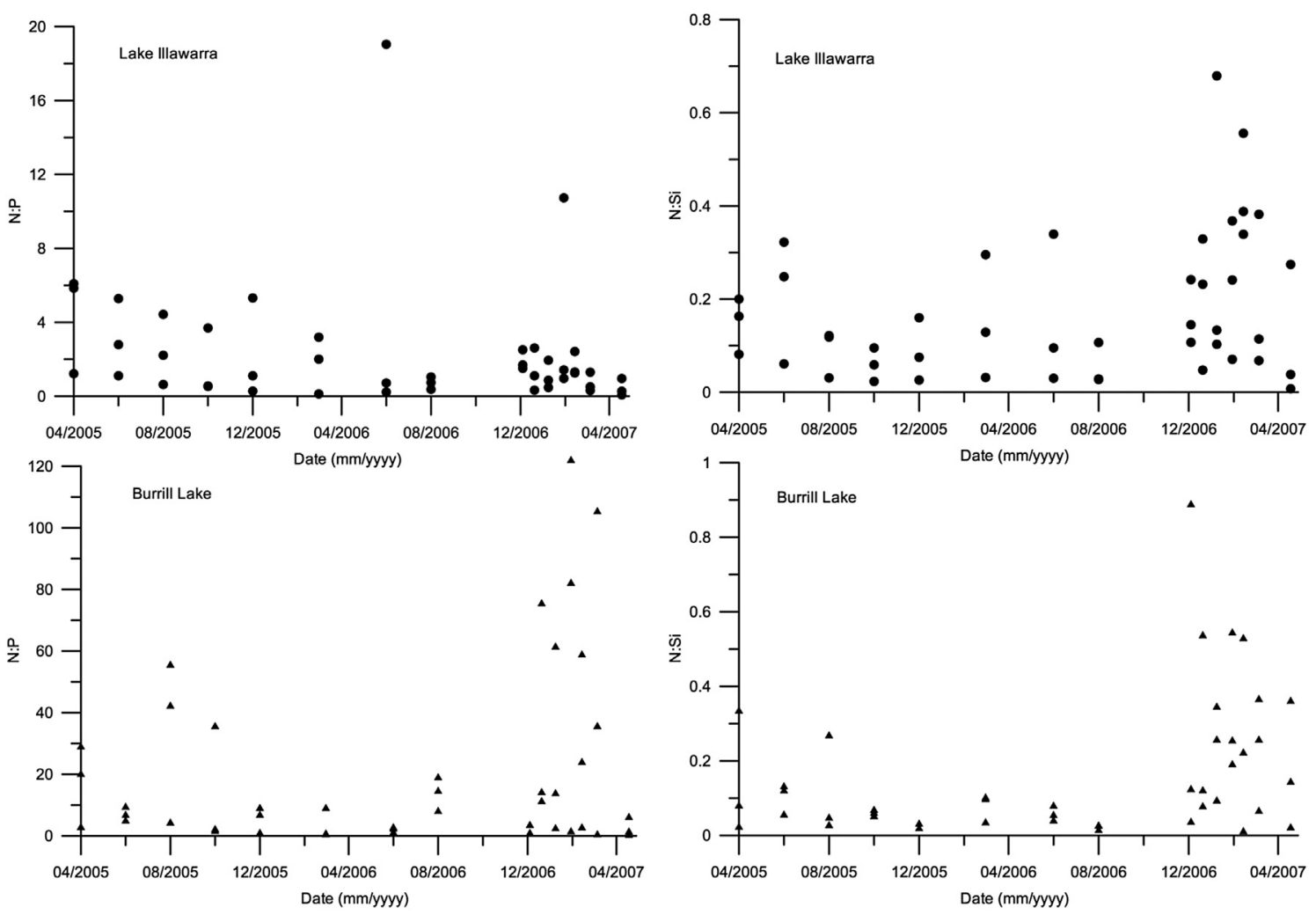

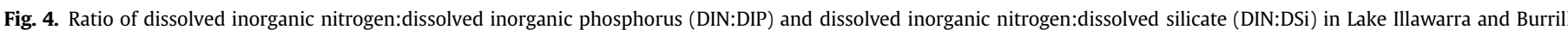
Lake.

2006 (Fig. 6). In 2007, no cell abundance data was acquired in February due to sample loss, Chl a concentration was higher in February and April compared to 2005 and 2006 (Table 3). Diatoms, such as, C. closterium, Pleurosigma nomanni and Thalassiosira rotula dominated in the phytoplankton assemblage (Fig. 6). In addition, Coelastrum sp., a species of Chlorophyta, displayed high abundance at Site 2 in some seasons of 2006 and 2007 (Fig. 6).

Lower phytoplankton biomasses were consistently found at the site close to seagrass meadows (Site 3 in Lake Illawarra), compared to the biomasses at the sites without seagrass meadows. The mean Chl a and cell abundance at Site 3 were $2.77 \mu \mathrm{g} / \mathrm{L}$ and $4.24 \times 10^{4}$ cells/L, respectively. In contrast, the mean $\mathrm{Chl}$ a and cell abundance at Site $1\left(3.66 \mu \mathrm{g} / \mathrm{L} ; 8.36 \times 10^{4}\right.$ cells/L) and Site $2(4.32 \mu \mathrm{g} / \mathrm{L}$; $6.61 \times 10^{4}$ cells $/$ L) displayed significant higher values (Fig. 5A and B).

\subsection{Annual pattern of phytoplankton assemblages in Burrill Lake}

The phytoplankton assemblage in Burrill Lake exhibited some distinct differences, spatially and temporally. In 2005, Chl a and cell abundance (average values from the three sites) displayed a typical winter maxima (June 2005, Table 3, Fig. 5C and D). An alternation of dinoflagellate and diatom dominance was observed in Burrill Lake (Fig. 7). The maximum biomass was mainly contributed by a dinoflagellate species Prorocentrum minimum (especially at Sites 2 and 3), although diatoms (Melosira jüergensi and Pesudo-nitzschia pungens) also occurred in high numbers at Sites 1 and 2 (Fig. 7).

In 2006, a winter maximum was observed again in Burrill Lake (Table 2, Fig. 5C and D). Dinoflagellate species (e.g., Alexandrium tamarense, Prorocentrum minimum, Dinophysis fortii) mainly contributed to this maximum biomass rather than the diatoms (e.g., Chhaetoceros debilis) which had relatively low biomass (Fig. 7). In 2007, phytoplankton biomass showed distinct increases in February and April (Table 2, Fig. 5C and D). The high Chl a concentration in April was caused by a bloom of Coelastrum sp. (Chlorophyta) at site 3 which displayed a particularly high cell abundance $\left(399 \times 10^{4}\right.$ cells/ $\mathrm{L}$ ) and Chl a concentration (55.3 $\mu \mathrm{g} / \mathrm{L}$ ). Dinoflagellates (Prorocentrum

Table 3

Phytoplankton species composition in Lake Illawarra and Burrill Lake (Diatom: Cyanophyta: $\Delta$; Chlorophyta: \$ ; Chromophyta: \$; Dinoflagellate: *; Present: +; Absent: -; FB: Freshwater to Brackish species; B: Brackish species; BM: Brackish to Marine species; M: Marine species; R: HAB species; T: Toxic species).

\begin{tabular}{|c|c|c|}
\hline \multirow[t]{2}{*}{ Species } & \multicolumn{2}{|l|}{ Estuaries } \\
\hline & Illawarra Lake & Burrill Lake \\
\hline \multicolumn{3}{|l|}{ Diatom } \\
\hline Achnanthes longipes C. Agardh $\bullet \mathrm{BM}$ & + & + \\
\hline Amphora hyalina Kützing • BM & + & - \\
\hline Asterionella japonica Cleve $\bullet \mathrm{M}, \mathrm{R}$ & + & - \\
\hline $\begin{array}{l}\text { Ardissonia crystallina } \\
\quad(\text { Agardh }) \text { Grunow } \bullet \mathrm{FB}\end{array}$ & + & - \\
\hline Bacillaria paradoxa J.F. Gmelin • M, R & + & + \\
\hline Biddulphia pulchella S.F. Gray • M & + & + \\
\hline $\begin{array}{l}\text { Cerataulina bicornis } \\
\quad \text { (Ehrenberg) Hasle @ M, R }\end{array}$ & + & + \\
\hline Cerataulina pelagica (Cleve) Hendey $\bullet \mathrm{M}$ & + & - \\
\hline Chaetoceros affinis Lauder $\bullet \mathrm{M}, \mathrm{R}$ & + & - \\
\hline Chaetoceros anastomosans Grunow $\bullet \mathrm{M}$ & + & + \\
\hline Chaetoceros brevis Schütt $\bullet \mathrm{M}$ & + & + \\
\hline Chaetoceros compressus Lauder $\bullet \mathrm{M}$ & + & + \\
\hline Chaetoceros constrictus Gran $\bullet \mathrm{M}$ & + & + \\
\hline Chaetoceros costatus Pavillard $\bullet \mathrm{M}$ & + & - \\
\hline Chaetoceros curvisetus Cleve $\bullet \mathrm{M}, \mathrm{R}$ & + & + \\
\hline Chaetoceros danicus Cleve $\bullet \mathrm{M}$ & + & + \\
\hline Chaetoceros debilis Cleve $\mathbf{M}, \mathrm{R}$ & + & - \\
\hline Chaetoceros decipiens Cleve $\bullet \mathrm{M}$ & + & + \\
\hline Chaetoceros didymus Ehrenberg $\bullet \mathrm{M}$ & + & + \\
\hline Chaetoceros laciniosus Schütt $\bullet \mathrm{M}$ & - & + \\
\hline
\end{tabular}


Table 3 (continued)

\begin{tabular}{|c|c|c|}
\hline \multirow[t]{2}{*}{ Species } & \multicolumn{2}{|l|}{ Estuaries } \\
\hline & Illawarra Lake & Burrill Lake \\
\hline Chaetoceros lauderi Ralfs in Lauder $\bullet \mathrm{M}$ & + & + \\
\hline Chaetoceros lorenzianus Grunow $\bullet \mathrm{M}, \mathrm{R}$ & + & + \\
\hline Chaetoceros peruvianus Brightwell $\bullet \mathrm{M}$ & + & + \\
\hline Chaetoceros pseudocurvisetus Mangin $\bullet \mathrm{M}$ & + & + \\
\hline Chaetoceros socialis Lauder $\bullet \mathrm{M}$ & + & - \\
\hline Chaetoceros similis Cleve $\bullet \mathrm{M}$ & - & + \\
\hline Chaetoceros teres Cleve $\bullet \mathrm{M}$ & + & - \\
\hline Climacosphenia moniligera Ehrenberg $\bullet$ FB & + & - \\
\hline Cocconeis placentula Ehrenberg $\bullet \mathrm{FB}$ & + & + \\
\hline $\begin{array}{l}\text { Coscinodiscus asteromphalus } \\
\text { Ehrenberg } \bullet \mathrm{M}, \mathrm{R}\end{array}$ & + & - \\
\hline Coscinodiscus centralis Ehrenberg $\bullet \mathrm{M}, \mathrm{R}$ & + & + \\
\hline Coscinidiscus concinnus W. Smith $\bullet \mathrm{M}, \mathrm{R}$ & + & + \\
\hline Coscinodiscus radiatus Ehrenberg $\bullet \mathrm{M}$ & + & + \\
\hline Coscinodiscus sp. $\bullet \mathrm{M}$ & + & + \\
\hline $\begin{array}{l}\text { Cylindrotheca closterium } \\
\text { (Ehrenberg) Lewin \& Reimann } \bullet \mathrm{BM}, \mathrm{R}\end{array}$ & + & + \\
\hline Diatoma hyalina Kützing $\bullet$ B & + & + \\
\hline Diploneis splendida Cleve & + & + \\
\hline Ditylum brightwellii Grunow $\bullet \mathrm{M}, \mathrm{R}$ & + & - \\
\hline Donkinia recta (Donkin) Grunow $\bullet$ & + & + \\
\hline Eucampia zodiacus Ehrenberg $\bullet \mathrm{M}, \mathrm{R}$ & + & - \\
\hline Fragilariopsis oceanica Hasle $\bullet \mathrm{B}$ & + & + \\
\hline Fragilariopsis doliolus Medlin \& Sims $\bullet$ B & + & + \\
\hline Guinardia delicatula (Cleve) Hasle • M & + & + \\
\hline Guinardia flaccida Castracane $\bullet \mathrm{M}$ & + & - \\
\hline Guinardia striata Hasle $\bullet \mathrm{M}$ & + & + \\
\hline Gyrosigma fascicola (Ehrenberg) Cleve $\bullet$ B & + & - \\
\hline Gyrosigma baltcum (Ehrenberg) Cleve $\bullet$ B & + & - \\
\hline Haslea wawrikae (Husedt) Simonsen $\bullet$ B & + & - \\
\hline Hemiaulus hauckii $\bullet \mathrm{M}$ & - & + \\
\hline $\begin{array}{l}\text { Hemidiscus hardmannianus (Greville) } \\
\text { Mann } \bigcirc \mathrm{M}\end{array}$ & - & + \\
\hline Lauderia borealis Gran $\bullet \mathrm{M}$ & + & + \\
\hline Leptocylindrus danicus Cleve $\bullet \mathrm{M}, \mathrm{R}$ & + & + \\
\hline Leptocylindrus mediterranneus Hasle $\bullet \mathbf{M}$ & + & + \\
\hline Leptocylindrus minimus Gran $\bullet \mathrm{M}, \mathrm{R}$ & + & + \\
\hline Licmophora abbreviate C. Agardh $\bigcirc \mathrm{B}$ & + & + \\
\hline Licmophora flabellata C. Agardh • B & + & + \\
\hline Lithodesmium undulatum Ehrenberg $\bullet \mathrm{M}$ & + & + \\
\hline Mastogloia minuta $\bullet$ B & + & + \\
\hline Melosira hyperborean Grunow $\bullet \mathrm{M}$ & + & + \\
\hline Melosira jüergensi C. Agardh $\bullet \mathrm{M}$ & + & + \\
\hline Navicula cancellata Donkin $\bullet$ B & + & + \\
\hline Navicula directa (W. Smith) Ralfs $\bullet$ B & + & + \\
\hline Navicula distans (W. Smith) Ralfs $\bullet$ B & + & + \\
\hline Navicula membranacea Cleve $\bullet \mathrm{B}, \mathrm{R}$ & + & + \\
\hline Navicula schroeteri F. Meister • B & + & + \\
\hline Nitzschia longissima Ralfs $\bullet \mathrm{M}, \mathrm{R}$ & + & + \\
\hline Nitzschia longissima var. reversa Grunow $\bullet \mathrm{M}$ & + & + \\
\hline Odontella obtusa Kützing • M & + & + \\
\hline Odontella reticulata (Roper) De Toni $\bullet \mathrm{M}$ & - & + \\
\hline Phaeodactylum tricornutum Bohlin • B & + & - \\
\hline Pleurosigma directum Grunow • B & + & + \\
\hline Pleurosigma intermedium W. Smith $\bullet$ B & + & + \\
\hline Pleurosigma rectum Donkin • B & + & + \\
\hline Pleurosigma normanii Ralfs $\bullet$ B & + & + \\
\hline $\begin{array}{l}\text { Pseudo-nitzschia delicatissima } \\
\text { (Cleve) Heiden } \bullet \mathrm{B}, \mathrm{R}\end{array}$ & + & + \\
\hline Pseudo-nitzschia subpacifica Hasle - B & + & - \\
\hline Pseudo-nitzschia prolongatoides Hasle • B & + & + \\
\hline Pseudo-nitzschia pungens Hasle $\bullet \mathrm{B}, \mathrm{R}$ & + & + \\
\hline Pseudo-nitzschia seriata H. Peragallo B & + & + \\
\hline Pseudo-nitzschia sp. $\bullet \mathrm{B}$ & + & + \\
\hline Rhabdonema adriaticum Kützing • BM & + & - \\
\hline Proboscia alata (Brightwell) Sündstrom • M & - & + \\
\hline Rhizosolenia setigera Brightwell • M, R & + & + \\
\hline Skeletonema costatum (Greville) Cleve $\bullet \mathrm{B}, \mathrm{R}$ & + & + \\
\hline $\begin{array}{l}\text { Striatella unipunctata (Lyngbye) } \\
\quad \text { C. Agardh } \bullet \mathrm{M}\end{array}$ & - & + \\
\hline $\begin{array}{l}\text { Tabellaria fenestrata (Lyngbye) } \\
\text { Kützing @ FB }\end{array}$ & + & - \\
\hline $\begin{array}{l}\text { Thalassionema frauenfeldii } \\
\quad \text { (Grunow) Hallegraeff } \bullet \mathrm{M}, \mathrm{R}\end{array}$ & + & + \\
\hline
\end{tabular}

Table 3 (continued)

\begin{tabular}{|c|c|c|}
\hline \multirow[t]{2}{*}{ Species } & \multicolumn{2}{|l|}{ Estuaries } \\
\hline & Illawarra Lake & Burrill Lake \\
\hline $\begin{array}{l}\text { Thalassionema nitzschioides } \\
\quad \text { (Grunow) Mereschkowsky } \bullet \mathrm{M}, \mathrm{R}\end{array}$ & + & + \\
\hline $\begin{array}{l}\text { Thalassiosira decipiens } \\
\quad \text { (Grunow) E.G. Jørgensen } \bullet \mathrm{M}\end{array}$ & + & + \\
\hline Thalassiosira hyalina (Grunow) Gran $\bullet \mathrm{M}$ & + & + \\
\hline Thalassiosira rotula Meunier $\mathrm{M}, \mathrm{R}$ & + & + \\
\hline $\begin{array}{l}\text { Thalassiosira subtilis (Ostenfeld) Gran } \\
\text { Dinoflagellate }\end{array}$ & + & - \\
\hline Akashiwo sanguinea $\mathrm{K}$. Hirasaka * M, R & + & + \\
\hline Alexandrium tamarense $\mathrm{E}$. Balech ${ }^{*} \mathrm{BM}, \mathrm{R}, \mathrm{T}$ & + & + \\
\hline Ceratium furca Ehrenberg * M, R & + & + \\
\hline Ceratium fusus Ehrenberg * M, R & + & + \\
\hline Ceratium macroceros Ehrenberg * $\mathrm{M}$ & + & + \\
\hline Ceratium tripos Nitzsch $* \mathrm{M}$ & + & + \\
\hline Dinophysis caudata Saville-Kent * M, R, T & + & + \\
\hline Dinophysis dens Pavillard * M & + & + \\
\hline Dinophysis diegensis Kofoid * $\mathrm{M}$ & + & + \\
\hline Dinophysis fortii Pavillard * M, R, T & + & + \\
\hline Dinophysis homunculus Stein * M & + & + \\
\hline Dinophysis ovum Schütt * $\mathrm{M}$ & + & + \\
\hline Gonyaulax monacantha Pavillard * $\mathrm{M}, \mathrm{R}$ & + & + \\
\hline Gonyaulax polygramma Stein * M, R & - & + \\
\hline Gonyaulax spinifera Diesing * M, R & + & + \\
\hline Gymnodinium lohmanni ${ }^{*} \mathrm{M}$ & - & + \\
\hline $\begin{array}{l}\text { Gymnodinium mikimotoi Miyake \& } \\
\text { Kominami ex Oda * M, R, T }\end{array}$ & + & + \\
\hline Gymnodinium sp.* M & + & + \\
\hline $\begin{array}{l}\text { Katodinium glaucum (Lebour) } \\
\text { Loeblich III * BM }\end{array}$ & + & - \\
\hline $\begin{array}{l}\text { Noctiluca scintillans (Macartney) } \\
\quad \text { Kofoid et Swezy * M, R }\end{array}$ & + & + \\
\hline Phalacroma rotundatum Kofoid \& Michener ${ }^{*} \mathrm{M}$ & - & + \\
\hline Prorocentrum gracile Schütt* $\mathrm{M}$ & + & + \\
\hline Prorocetrum lima (Ehrenberg) Dodge ${ }^{*} \mathrm{M}, \mathrm{R}, \mathrm{T}$ & + & + \\
\hline Prorocentrum mexicanum Tafall $* \mathrm{M}, \mathrm{R}, \mathrm{T}$ & - & + \\
\hline Prorocentrum micans Ehrenberg * M, R & + & + \\
\hline Prorocentrum minimum (Pavillard) Schiller * BM & + & + \\
\hline Protoperidinium conicum (Gran) Balech * M & + & + \\
\hline Protoperidinium depressum (Bailey) Balech * M & + & + \\
\hline Protoperidinium grande (Kofoid) Balech * M & + & + \\
\hline Protoperidinium pallidum (Ostenfeld) Balech * $\mathrm{M}$ & + & + \\
\hline Protoperidinium pentagonum (Gran) Balech * M & + & + \\
\hline Protoperidinium sp.* M & - & + \\
\hline Protoperidinium steinii (Jørgensen) Balech * M & + & + \\
\hline Protoperidinium pyriforme (Paulsen) Balech * M & + & + \\
\hline $\begin{array}{l}\text { Pyrophacus steinii (Schiller) } \\
\quad \text { Wall \& Dale * M }\end{array}$ & + & + \\
\hline $\begin{array}{l}\text { Scrippsiella trochoidea (Stein) } \\
\quad \text { Balech ex Loeblich III * B, R }\end{array}$ & + & + \\
\hline Cyanophyta & & \\
\hline $\begin{array}{l}\text { Trichoclesmium erythraeum } \Delta \mathrm{M} \\
\text { Chlorophyta }\end{array}$ & + & + \\
\hline $\begin{array}{l}\text { Chlamydomonas reginae } \\
\text { Ettl \& Green } \& \text { BM }\end{array}$ & + & + \\
\hline $\begin{array}{l}\text { Coelastrum sp. \& FB, } \mathrm{R} \\
\text { Chromophyta }\end{array}$ & + & + \\
\hline Dictyocha fibula Ehrenberg \$ M & + & + \\
\hline $\begin{array}{l}\text { Mesocena polymorpha } \\
\text { Lemmerman } \$ \mathrm{M}\end{array}$ & - & + \\
\hline
\end{tabular}

minimum, Dinophysis fortii and Gymnodinium lohmanni), diatoms (Thhalassiosira rotula and Chaetoceros deblis) and Chlorophyta (Coelastrum sp.) were observed in high numbers (Fig. 7).

Similarly, lower phytoplankton biomasses were found at the site close to seagrass meadows (Site 1 in Burrill Lake), where phytoplankton biomass at Site 1 near large meadows of seagrass displayed the lowest values (Chl a: $2.10 \mu \mathrm{g} / \mathrm{L}$; cell abundance: $12.4 \times 10^{4}$ cells/L) (Fig. 5), which was lower than the average biomass value of the lake (Table 2 ).

Another important factor influencing "within-lake" variability in phytoplankton biomass is freshwater discharge, which can be 

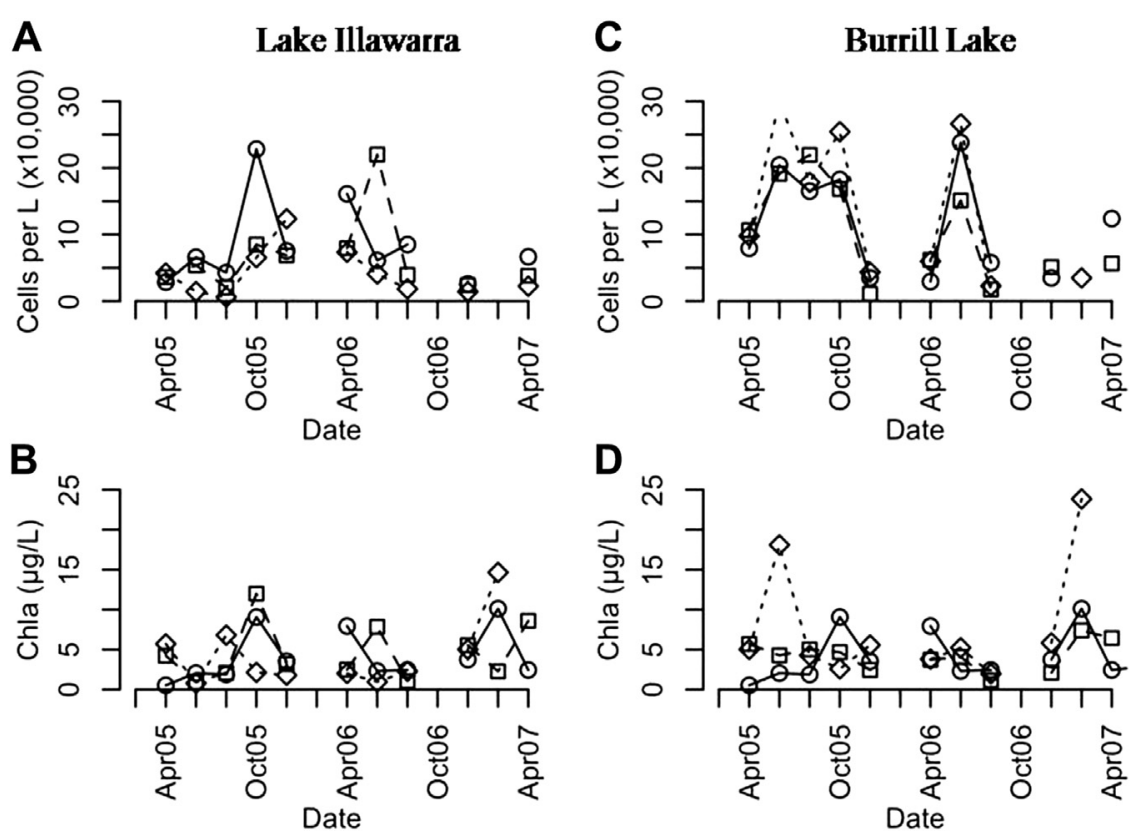

Fig. 5. Phytoplankton cell abundance and chlorophyll a in surface waters at each of the three sites in Lake Illawarra (A, B) and Burrill Lake (C, D).

a source of dissolved nutrients, contributing to significantly increased primary productivity. In this study, phytoplankton biomasses at Site 3 in Burrill Lake, located near a freshwater creek discharge, displayed high values after the heavy rain, as well as an algal blooming event. This most likely reflected a response to the relative high nutrient concentrations during runoff events.

\subsection{Phytoplankton biomass and environmental factors}

A stepwise method of multi-linear regression was used to investigate correlations between phytoplankton biomass and environmental factors (Table 4). In terms of nutrients, only DIP concentrations displayed significant correlations with the average
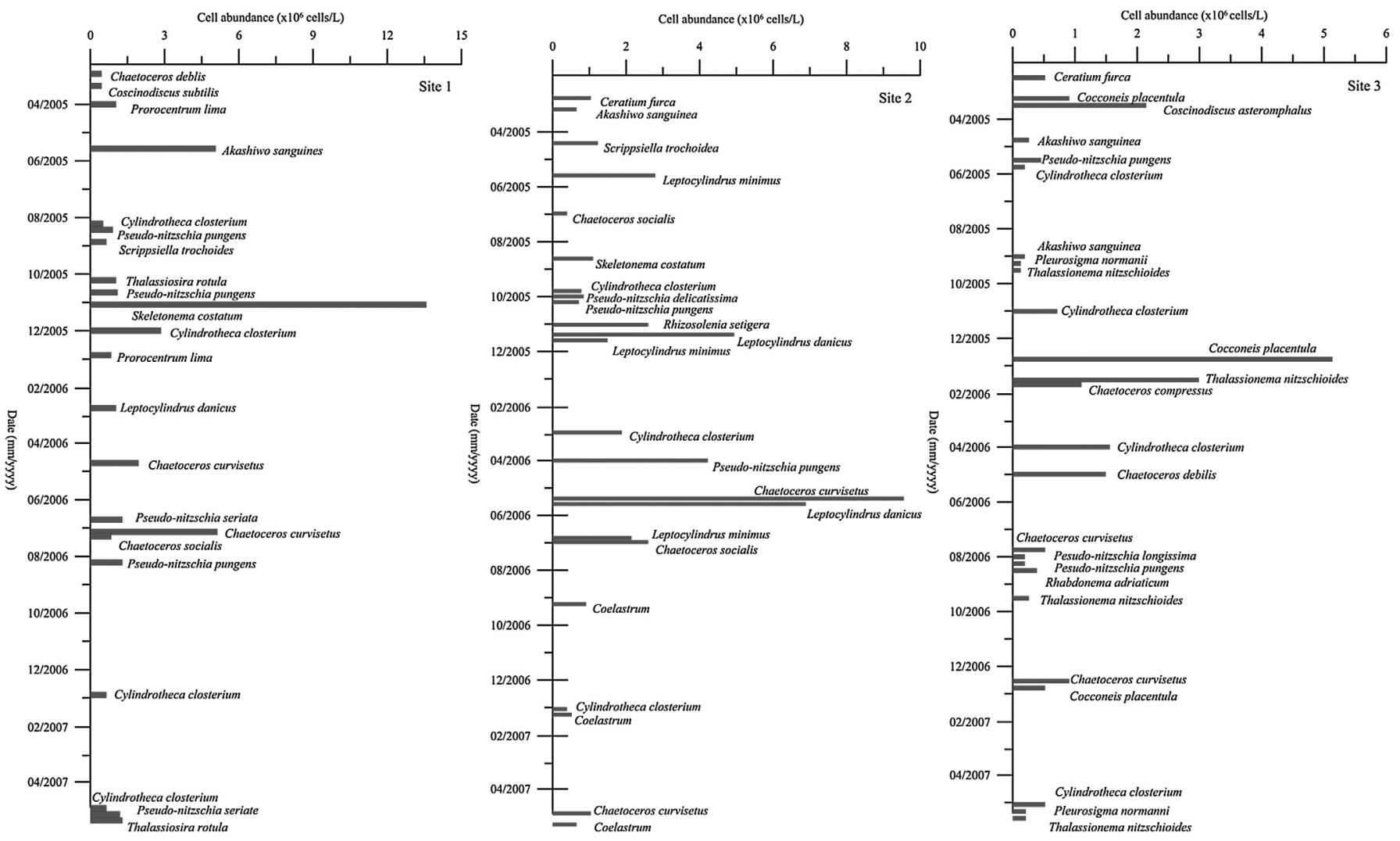

Fig. 6. Cell abundance of dominant phytoplankton species in Lake Illawarra on each sampling occasion, shown for each site. 

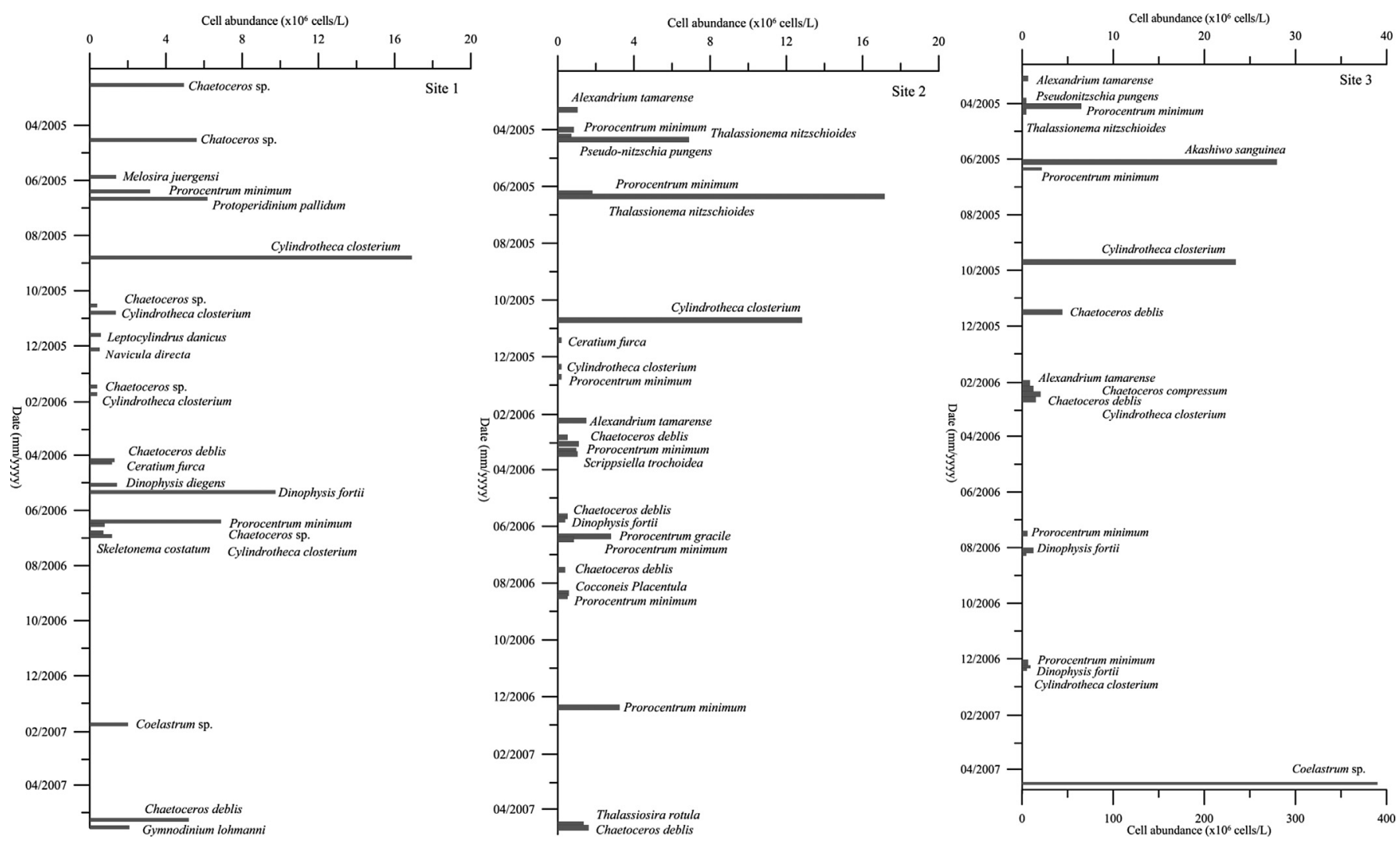

Fig. 7. Cell abundance of dominant phytoplankton species in Burrill Lake on each sampling occasion, shown for each site.

phytoplankton biomass in Lake Illawarra; for physical factors, a significant correlation was found between water temperature and phytoplankton biomass, indicating the impact of temperature on the seasonal pattern of phytoplankton in Lake Illawarra (Tables 3 and 4). Bivariate correlations were conducted between phytoplankton biomass and nutrients for each of the three sampling sites in Lake Illawarra. DIN and DIP did not display significant correlations with phytoplankton biomass at the site level, although some correlations were found for Site 3, which is adjacent to large areas of seagrass. DISi showed significant correlations with phytoplankton at Site 3, probably indicative of the impact of freshwater discharge (Table 4).

No significant correlations were found between nutrients and the average phytoplankton biomass for Burrill Lake (Table 4). Little previous nutrient information has been reported for Burrill Lake. Correlations between phytoplankton biomass and nutrients were

Table 4

Correlations between phytoplankton biomass and environmental factors in Lake Illawarra and Burrill Lake ( $P$ : Pearson's Correlation Coefficient; S: Significance (2tailed)).

\begin{tabular}{lccccc}
\hline Items & \multicolumn{2}{l}{$\begin{array}{l}\text { Phytoplankton biomass in } \\
\text { Lake Illawarra }\end{array}$} & & \multicolumn{2}{l}{$\begin{array}{l}\text { Phytoplankton biomass } \\
\text { in Burrill Lake }\end{array}$} \\
\cline { 2 - 3 } \cline { 5 - 6 } \cline { 5 - 6 } & $P$ & $S$ & & $P$ & $S$ \\
\hline DIN & 0.06 & 0.43 & & 0.33 & 0.35 \\
DIP & 0.53 & 0.05 & & 0.43 & 0.09 \\
DSi & 0.07 & 0.42 & & -0.03 & 0.93 \\
DIN:DIP & -0.28 & 0.20 & & 0.25 & 0.48 \\
DIN:DSi & -0.25 & 0.23 & & 0.22 & 0.54 \\
Temperature & 0.60 & 0.03 & & 0.24 & 0.50 \\
Salinity & -0.35 & 0.15 & & 0.63 & 0.03 \\
Turbidity & 0.27 & 0.21 & & 0.08 & 0.84 \\
Rainfall & 0.38 & 0.15 & & 0.31 & 0.44 \\
\hline
\end{tabular}

also investigated on a site-by-site basis for Burrill Lake. No significant correlations were found, although low correlations were displayed at Site 1, which is adjacent to seagrass beds and at Site 3, near to the freshwater creek. Salinity displayed a significant correlation with phytoplankton biomass. These results indicated an impact of freshwater input on the phytoplankton biomass in Burrill Lake.

\section{Discussion and conclusions}

In this study, we found that phytoplankton species in two lakes were mainly composed of two groups, diatoms and dinoflagellates. Their ecological characteristics indicated a typical feature of warm temperate estuaries, with a mix of marine and brackish species. Unlike a typical seasonal pattern in temperate waters with a spring maximum of phytoplankton biomass (Dawes, 1997), we only observed one obvious spring maximum during the sampling period (Lake Illawarra in October 2005). Winter maxima of phytoplankton biomass occurred in both Lake Illawarra (2006) and Burrill Lake (2005 and 2006). This may be a result of the warm temperate climatic regime, with the water temperatures in winter $\left(>10^{\circ} \mathrm{C}\right)$ staying higher compared to typical temperate and cold temperate areas (Fig. 2A and D). High temperature throughout winter sustained the growth of phytoplankton and may result in winter maxima.

There are several distinct differences between the two lakes after comparison. In terms of the water quality parameters measured in this study, salinity, turbidity and nutrients displayed distinct differences between the two lakes. Higher salinity observed in Burrill Lake during the sampling period, compared to Lake Illawarra (Fig. 2B and E). Differences in salinity are probably related to the size of the lakes and amount of freshwater discharge into the lakes, as well as the frequency of opening of the entrance to the sea. Lake Illawarra has a larger area and more creeks compared 
to Burrill Lake. Moreover, during the sampling period, Lake Illawarra was only open twice for a short period, whereas Burrill Lake was frequently open (Lake Illawarra Authority, 2007; personal communication).

Higher turbidities in Lake Illawarra, when compared to Burrill Lake (Fig. 2C and F), are probably a combination of human activity and hydrodynamic conditions. There is a higher level of human activity around Lake Illawarra which resulted in large quantities of domestic and industrial waste-waters, urban drainage and agricultural effluents. In addition, Lake Illawarra is particularly susceptible to wind driven currents and waves because it is shallow and has a large surface area, and higher wind and wave action around the Lake Illawarra often re-suspends bottom sediments (Morrison and West, 2004) causing high turbidity.

In general, DIN and DISi displayed slightly higher values in Lake Illawarra compared to Burrill Lake, but particularly higher DIP concentrations were observed in Lake Illawarra (Fig. 3B and E). Increasing nutrient concentrations have been attributed to the intensive human activity around the lake (LIA, 1995; Rutten et al., 2004; Scanes et al., 2007), but previous studies have also pointed out that the catchment of Lake Illawarra has significant areas of basaltic rocks, high in phosphorus (Branagan and Packham, 2000). Thus, the higher DIP concentrations in Lake Illawarra reported here might be a result of natural conditions, combined with human activity. Overall, Lake Illawarra usually had higher proportion of nitrogen limitation. By comparison, the nutrient structure in Burrill Lake was more variable, showing a combination of nitrogen and phosphorus limitation.

Interestingly, the results from this study were not completely consistent with the hypothesis that phytoplankton biomass should necessarily be higher in heavily human impacted water bodies. Major differences of phytoplankton assemblages between the two lakes were not reflected in the general species composition and total biomass increase but in the dominance shifts. In Lake Illawarra, diatoms dominated the phytoplankton assemblages during most seasons and years (Fig. 6), whereas in Burrill Lake, diatom and dinoflagellate dominance shifted in seasons, and dinoflagellate dominances were generally more prevalent over the whole year (Fig. 7). For example, Prorocentrum minimum was a dominated species found for most of the year in Burrill Lake. This species is considered responsible for large-scale and serious poisoning of humans in many parts of the world, usually through the accumulation of toxins in clams (e.g., Okaichi, 2004). Other toxic species among the samples, such as Dinophysis fortii and Alexandrium tamarense, were also dominant in some seasons at some locations (Fig. 7). These two species have been reported to produce diarrhetic shellfish poisoning (DSP) and contaminate shellfish (Yasumoto et al., 1980). Even low cell concentrations of Dinophysis fortii (such as $<100$ cells/L) are of concern, and can make shellfish toxic; thus, early warning through monitoring is very important for this species (Okaichi, 2004).

It is difficult to explain such large differences in dominant phytoplankton groups between the two lakes; however, the different nutrient regimes found for the two lakes may provide some explanation. As indicated above, during this study, Lake Illawarra was characterized by a distinct $\mathrm{N}$-limitation and phosphate surplus (Fig. 5). Previous studies have shown that diatoms outcompete various dinoflagellate species under $\mathrm{N}$-limiting conditions (Heckey and Kilham, 1988; Sommer, 1993). Diatoms also have been recognized as superior competitors for phosphorus (Tilman et al., 1986; Heckey and Kilham, 1988). Thus, the current nutrient regime in Lake Illawarra may provide a more suitable growth medium for diatoms relative to dinoflagellates. However, the nutrient regime in Burrill Lake was more variable than in Lake Illawarra. Optimal ratio of DIN:DIP, N-limitation and P-limitation altered regularly during the sampling period (Fig. 5). This leads to the likelihood of many different species dominating the assemblages at different times. In general, dinoflagellates, especially HAB species, are typical opportunists, showing faster growth rate and nutrient uptake under "reasonable" nutrient conditions (Harding et al., 1983; Okamoto and Hirano, 1987; Nielsen et al., 1995; Lomas and Glibert, 2000). Thus, the highly variable nutrient regime in Burrill Lake could create advantageous growing conditions for dinoflagellates. Unfortunately, the stepwise multi-linear regression used to investigate correlations between phytoplankton biomass and associated environmental factors provided little insight into the underlying processes controlling phytoplankton biomasses in these two lakes (Table 4).

Lower biomasses were observed at the sites with large seagrass meadows (e.g., Site 3 in Lake Illawarra; Site 1 in Burrill Lake) in our study. Previous studies have indicated that phytoplankton assemblages between open water and seagrass habitats can display significant differences in species composition and biomass (Cummins et al., 2004). Competition between seagrass and epiphytic algae for nutrients (Kinney and Roman, 1998) and the reduction of flow velocities by patches of seagrass (Fonseca et al., 1982; Eckman, 1987) could be factors leading to a decrease in the biomass of phytoplankton.

In a summary, the comparison of phytoplankton assemblages in the two lakes indicated that biomass cannot completely reflect the status of water quality without species information. In fact, toxic dinoflagellate species were obviously more dominant in the less impacted lake, namely Burrill Lake. This finding raises concerns about the management of this particular lake, as well as the reliance on simplified "indicators", such as chlorophyll, in assessing estuary health. Phytoplankton species assemblages and biomasses in these two coastal lakes were influenced by a number of factors other than simple nutrient concentrations, such as, physical attributes of the lake (e.g., depth and lake area); catchment chemistry (e.g., type of rock substrate underlying the lakes); ratios of dissolved nutrient (e.g., deviations from the Redfield ratio); freshwater discharges and saltwater intrusions; and, competition for resources (e.g., from algae and seagrasses). The overwhelming importance of such local environmental factors, all of which are highly variable between individual locations, makes generalizations about the lakes in SE Australia very difficult and further reinforces the need for more extensive investigation rather than the sole reliance on estuary health indicators.

\section{Acknowledgements}

The senior author would like to acknowledge international postgraduate scholarship support from the University of Wollongong. This project was funded in part by the Lake Illawarra Authority, the CAS Innovative Programmer (No. KZCX2-YW-Q0704) and National Natural Science Foundation of China (No. 40976097).

\section{References}

ABS, 2003. Census of Population and Housing: Selected Characteristics for Urban Center and Localities, New South Wales and Australian Capital Territory. Australian Bureau Statistics, Canberra.

Ajani, P., Lee, R., Pritchard, T., Krogh, M., 2001. Phytoplankton dynamics at a long term coastal station off Sydney, Australia. Journal of Coastal Research 34 60-73.

APHAAWWAWPCF, 1998. Standard Methods for the Examination of Water \& Wastewater, twentieth ed. American Public Health Association, Washington, D.C.

Branagan, D., Packham, G., 2000. Field Geology of New South Wales. New South Wales Department of Mineral Resources, Sydney.

Chafer, C.J., Brandis, C.C.P., 2001. Changes in the waterbird community of the Lake Illawarra estuary: 20 years of research. Wetlands (Australia) 21, 183-202. 
Cummins, S.P., Roberts, D.E., Ajani, P., Underwood, A.J., 2004. Comparisons of assemblages of phytoplankton between open water and seagrass habitats in a shallow coastal lagoon. Australian Journal of Marine and Freshwater Research 55, 47-456.

Dawes, C.J., 1997. Marine Botany. John Wiley, New York, 480 pp.

Eckman, J.E., 1987. The role of hydrodynamics in recruitment, growth, and surviva of Argopecten irradians (L.) and Anomia simplex (d'Orbigny) within eelgrass meadows. Journal of Experimental Marine Biology and Ecology 106, 165-191.

Fenner, J., Schrader, H.J., Wienigk, H., 1976. Diatom phytoplankton studies in the southern Pacific Ocean: composition and correlation to the Antarctic convergence and its paleoecological significance. In: Hollister, C.D., Craddock, C., et al. (Eds.), 1976. Initial Reports. DSDP, vol. 35. U.S. Govt. Printing Office, Washington, pp. 757-813.

Fonseca, M.S., Fisher, J.S., Zieman, J.C., Thayer, G.W., 1982. Influence of the seagrass, Zostera marina L., on current flow. Estuarine, Coastal and Shelf Science 15, 351-364.

Guo, Y., Qian, S., 2003. Bacillariophyta in Flora Algarum Marinarum Sinicarum. Science Press, Beijing, 447 pp. (in Chinese).

Harding Jr., L.W., Meeson, B.W., Tyler, M.A., 1983. Photoadaptation and diel periodicity of photosynthesis in the dinoflagellate Prorocentrum mariae-lebouriae. Marine Ecology Progress Series 13, 73-85.

Hasle, G.R., 1976. The biogeography of some marine planktonic diatoms. Deep-Sea Research 23, 319-338.

Hasle, G.R., Syvertsen, E.E., 1997. Marine diatoms. In: Tomas, C.R. (Ed.), Identifying Marine Diatoms and Dinoflagellates. Academic Press, San Diego, pp. 5-386.

Heckey, R.E., Kilham, P., 1988. Nutrient limitation of phytoplankton in freshwate and marine environments: a review of recent evidence on the effects of enrichment. Limnology and Oceanography 33, 796-822.

Jeffrey, S.W., Humphrey, G.F., 1975. New spectrophotometric equations for determining chlorophyll a, b, c1 and c2 in higher plants, algae and natural phytoplankton. Biochemie und Physiologie der Pflanzen 167, 191-194.

Jones, M.V., West, R.J., 2005. Spatial and temporal variability of seagrass fishes in intermittently closed and open coastal lakes in southeastern Australia. Estuarine, Coastal and Shelf Science 64, 277-288.

Kinney, E.H., Roman, C.T., 1998. Response of primary producers to nutrient enrichment in a shallow estuary. Marine Ecology Progress Series 163, 89-98.

LIA, 1995. Lake Illawarra Works Program Environmental Appraisal (Impact on Lake Nutrient Dynamics). Lake Illawarra Authority, Wollongong.

Lomas, M.W., Glibert, P.M., 2000. Comparison of nitrate uptake, storage and reduction in marine diatoms and dinoflagellates. Journal of Phycology 36, 903-913.
Morrison, R.J., West, R.J., 2004. Science and management of Lake Illawarra editorial. Wetlands (Australia) 21 (2), 56.

Nielsen, T., Bjorn, L.O., Ekelund, N.G.A., 1995. Impact of natural and artificial UV-B radiation on motility and growth rate of marine dinoflagellates. Journal of Photochemistry Photobiology B: Biology 27, 73-79.

NSW Department of Water, 2009. http://www.water.nsw.gov.au/WaterManagement/Water-quality/Algal-information/default.aspx. (accessed December 2009).

Okaichi, T., 2004. Red Tides. Kluwer Academic Publishers, Dordrecht, London, Boston, $432 \mathrm{pp}$.

Okamoto, K., Hirano, R., 1987. Growth response of natural populations of red tide organisms to nutrient enrichment. In: Okaichi, T., Anderson, D.M., Nemoto, D.M. (Eds.), Red Tides: Biology, Environmental Science and Technology. Elsevier, New York, pp. 233-236.

Roy, P.S., Williams, R.J., Jones, A.R., Yassini, R., Gibbs, P.J., Coates, B., West, R.J., Scanes, P.R., Hudson, J.P., Nichol, S., 2001. Structure and function of south-east Australian estuaries. Estuarine, Coastal and Shelf Science 53, 351-384.

Rutten, K., Morrison, R.J., West, R.J., 2004. Macroalgae in Lake Illawarra, New South Wales, Australia. Wetlands (Australia) 21 (2), 103-114.

Scanes, P., Coade, G., Doherty, M., Hill, R., 2007. Evaluation of the utility of water quality based indicators of estuarine lagoon condition in NSW, Australia. Estuarine, Coastal and Shelf Science 74, 306-319.

SCC, 2002. Shoalhaven City Council State of the Environment Report 2002. Shoalhaven City Council, New South Wales, Australia.

Sommer, U., 1993. Phytoplankton competition in Pluee: a field test of the resource ratio hypothesis. Limnology and Oceanography 38, 838-845.

Tilman, D., Kilham, S.S., Kilham, P., 1986. Phytoplankton community ecology: the role of limiting nutrients. Annual Review of Ecological Systematics 13, 349-372.

Utermöhl, H., 1958. Zur Vervolkommung der quantitativen Phytoplankton-Methodik. Mitteilungen Internationale Vereiningung fur Theoretische und Angewandte Limnologie 9, 1-38.

WBM, 2003. Lake Illawarra Estuary Processes Study. Final Report to the Lake Illawarra Authority. WBM Oceanics Australia, Springhill, Queensland.

West, R.J., 2004. Effect of climate and human induced changes on the seagrasses in Lake Illawarra. Wetlands (Australia) 21 (2), 124-137.

Woodroffe, C.D., 2003. Coasts: Form, Process and Evolution. Cambridge University Press, UK, $623 \mathrm{pp}$.

Yasumoto, T., Oshima, Y., Murakami, Y., Nakajima, I., Bagnis, R., Fukuyo, Y., 1980 Toxicity of benthic dinoflagellates found in coral reefs. Bulletin of the Japanese Society of Fisheries Science 46, 327-331. 